Research Note

Journal of Extension Education

Vol. 28 No. 1, 2016

\title{
Constraints Faced by m-Kisan Users
}

\section{Jayanthi ${ }^{1}$ and M. Asokhan ${ }^{2}$}

Mobile phone technology has been diffused rapidly in the rural areas of the developing countries in recent years. It has the advantage over other ICT tools in terms of its appropriateness for the underdeveloped local conditions. Other than mobile phones, other ICT tools suffers from the problem of feasibility for the poor in geographically disadvantaged areas because of lack of enabling environments such as infrastructure and capital. Internet enhanced technologies are not appropriate in the areas lacking electricity and network infrastructure. On the contrary, mobile phone technology has much less requirement on the infrastructure and hence wider applicability especially in mountainous areas. Mobile phones enable both audio and video functions which can meet most of the basic needs of the poor. It also has greater affordability for the farmers than internet.

In many developing countries more than 80 per cent of the population have access to mobile phones. Jensen (2007) demonstrated that the ICT helped fishers along the coastline in Kerala, India learn about prices at different locations and decide where to sell their products profitably. As a result, price volatility and variation dropped; producer prices rose and at the same time consumer prices dropped. Aker (2008) studied the impact of the mobile phone rollout on grain markets in Niger and show that mobile phone service has reduced grain price dispersion across markets by a minimum of 6.4 percent and reduced intra-annual price variation by 10 per cent.

The m-Kisan SMS Portal was inaugurated by the President of India on July 16, 2013. SMS Portal for farmers enables all Central and State government organizations in agriculture and allied sectors (including State Agriculture Universities, Krishi Vigyan Kendras, Agromet Forecasts Units of India Meteorological Department, ICAR Institutes, Organization in Animal Husbandry, Dairying \& Fisheries etc.) for the purpose of giving information or services or advisories to farmers by SMS in their language, preference of

1. Research Scholar, and 2. Professor \& Head, Dept. of Agricultural Extension \& Rural Sociology, TNAU, Coimbatore, India 
agricultural practices and location. The project conceptualized, designed and developed in-house within the Department of Agriculture \& Co-operation has widened the outreach of scientists, experts and government officers posted down to the block level to disseminate information and to provide advisories to farmers through their mobile phones. The ICT initiative has to be evaluated for better serving the farmers. The objective of the study was to find out the constraints faced by the farmers while accessing mobile agricultural extension services.

\section{METHODOLOGY}

Pudukottai and Ramanathapuram districts were selected purposively for the study based on the familiarity of the researche. Pudukottai and Ramanathapuram districts had 13 and 11 blocks respectively. Out of these, two blocks have been selected from each district and a total of four blocks were selected based on highest number of users in respective districts. The selected blocks were Thiruvarakulam, Karambakudi, Kamudi and Mudukulathur. Two villages from each block were selected based on the discussion with the officials of State Department of Agriculture of the respective blocks. A list of farmers who were receiving agricultural information through m-Kisan was obtained from the office of Joint Director of Agriculture in Pudukottai and Ramanathapuram

Table 1. Distribution of Respondents According to Constraints Faced While Availing Mobile Agricultural Extension Services

$(\mathrm{n}=\mathbf{1 2 0})$

\begin{tabular}{|c|l|c|c|}
\hline S1. & \multicolumn{1}{|c|}{ Constraints* } & \multicolumn{1}{|c|}{ m-Kisan } \\
\cline { 3 - 4 } No. & \multicolumn{1}{|c|}{ No. } & \% \\
\hline 1. & No direct contact with scientists & - & - \\
\hline 2. & No follow-up visit by field coordinators after giving advice & 63 & 52.50 \\
\hline 3. & Untimely receipt of message & 24 & 20.00 \\
\hline 4. & Time of broadcasting and conferring is not convenient & 32 & 26.67 \\
\hline 5. & Clarification is difficult if any doubt arises & 60 & 50.00 \\
\hline 6. & Lack of information about multiple crops & 48 & 40.00 \\
\hline 7. & Problems of foreign language & 49 & 40.83 \\
\hline 8. & Lack of locally relevant information & 70 & 58.33 \\
\hline 9. & Lack of information about supporting services like logistics and & 34 & 28.33 \\
\hline 10. & Lack of clarity on price fixation in markets & 83 & 69.17 \\
\hline
\end{tabular}

${ }^{*}$ Multiple responses 
district. Totally 15 farmers from each village were identified which sum up to a total of 120 respondents. Percentage analysis was used to study the constraints faced by m-Kisan users.

\section{FINDINGS AND DISCUSSION}

The distribution of respondents according to the constraints faced while availing mobile agricultural extension services is presented in Table 1.

It is concluded from Table 1 that among m-Kisan users, 69.17 per cent of the respondents expressed that lack of clarity on price fixation in markets followed by 58.33 per cent of the respondents were facing lack of locally relevant information and 52.50 per cent of the respondents indicated that there was no follow-up visit by field coordinators after giving advice. The respondents were also facing the constraints viz. clarification is difficult if any doubt arise (50.00\%), problems of foreign language (40.83\%), lack of information about multiple crops (40.00\%), lack of information about supporting services like logistics and storage $(28.33 \%)$, time of broadcasting and conferring is not convenient $(26.67 \%)$ and untimely receipt of message $(20.00 \%)$ respectively.

m-Kisan had made an attempt to offer location specific services to the farmers. To offer more effective location specific advice to farmers, a combination of both personal and ICT approach is suggested. Participatory rural appraisals may be carried out periodically to ascertain what information the farmers need. In the process, the farmers' faith in the information services provided will be enhanced. It is further recommended that the farmers be instructed through various extensions efforts on how to get the best possible use out of the services provided.

\section{References}

Aker, J. C. (2008). Does Digital Divide or Provide? The Impact of Mobile Phones on Grain Markets in Niger. BREAD Working Paper, 177.

Jensen, R. (2007). The Digital Provide: Information (Technology) Market Performance and Welfare in the South Indian Fisheries Sector, The Quarterly Journal of Economics, 122(3), 879-924.

Koshy, S.M.\& Kishorekumar. N (2015). A Scale to measure the attitude of farmers, towards Kisan Call Centre Journal of Extension Education, 27(4)

Planning Commission. (2007). Working group on agricultural extension for formulation of Eleventh Five-Year Plan. Government of India. 